\title{
Filozofia człowieka Paula Ricoeura jako sposób na obronę współczesnej podmiotowości
}

\author{
Adriana Warmbier, Tożsamość, narracja i hermeneutyka siebie. Paula Ricoeura \\ filozofia człowieka, Universitas, Kraków 2018, ss. 380.
}

Cow

o w ramach filozofii człowieka można współcześnie powiedzieć o „podmiocie”? O jego „śmierci” mówiono już wielokrotnie. Adriana Warmbier zagadnieniu podmiotu i filozofii człowieka poświęca swoją książkę Tożsamość, narracja i hermeneutyka siebie. Paula Ricoeura filozofia człowieka. Przedstawia w niej Ricoeurowski pomysł na podmiot. Co może zrobić współczesny myśliciel, któremu odległe jest kartezjańskie myślenie o podmiocie, ale z drugiej strony nie chce się pogodzić z jego „śmiercią”? Filozofia Paula Ricoeura jest bardzo ważną propozycją odpowiedzi na to pytanie i nie można jej pominąć.

Adriana Warmbier zajmuje się filozofią człowieka, szczególnie zagadnieniem podmiotowości. W tym kontekście interesują ją zagadnienia związane na przykład z transhumanizmem. Analizując kategorią podmiotowości, autorka nie po raz pierwszy odwołuje się do prac Paula Ricoeura. Wcześniej uczyniła to na przytkład w pracy Podwójna struktura podmiotowości. O Ricoeurowskiej lekturze Kartezjusza, w której wskazuje kartezjańskie wątki obecne w koncepcji podmiotu Ricoeu$\mathrm{ra}^{1}$. Autorka w książce zręcznie i obszernie analizuje Ricoeurowskie rozumienie

${ }^{1}$ A. Warmbier, Podwójna struktura podmiotowości. O Ricoeurowskiej lekturze Kartezjusza, „Ruch Filozoficzny” 2/2013, ss. 331-350. 
podmiotowości. Z pewnością perspektywę filozoficznej refleksji nad poglądami francuskiego myśliciela poszerza przywołanie jego tekstów, które dotychczas nie były tłumaczone na język polski.

Warmbier w swojej książce w sposób dokładny, krok po kroku, prowadzi czytelnika poprzez kolejne elementy filozofii człowieka Ricoeura. Z trzech perspektyw omawia filozofię podmiotu otwartej dialektyki. Po pierwsze, robi to na sposób historyczny (hermeneutyczno-interpretacyjny) - przedstawia, jak formowało się stanowisko Ricoeura, odnosząc się do pytań, kontekstów i sporów, w którym omawiał on problemy dotyczące podmiotu. Po drugie, używa porównawczego podejścia metodologicznego - ukazuje Ricoeurowskie poglądy na tle innych ujęć podmiotowości. Po trzecie, refleksja Warmbier nad filozofią podmiotu otwartej dialektyki jest podejmowana w sposób analityczno-krytyczny - to ocena postkrytycznego sposobu rozumienia pojęcia podmiotu.

W książce za punkt wyjścia refleksji nad podmiotem służy przywołanie Kartezjańskiej koncepcji podmiotu i jej późniejszej krytyki. Co ciekawe, autorka wskazuje na istnienie pewnej wyrwy w ujęciu podmiotu u Kartezjusza ${ }^{2}$. W Rozprawie o metodzie, a także w Medytacjach o pierwszej filozofii pojawiają się formuły ego cogito, ego sum oraz ego sum, ego existo. Warmbier zauważa, że Ricoeur raczej nie korzysta z możliwości, jakie daje podwójna struktura Kartezjańskiego podmiotu, o czym pisali już m.in. Nabert, Lévinas czy Marion, a więc z przejścia poprzez zapośredniczenia do orzekania o subiektywności istniejącej w czasie, czyli w historii, w języku, w kulturze z innymi i wobec innych. Ricoeur to przejście widzi w czynności teoretycznej, jaką jest postulat poszerzenia sensu refleksji ${ }^{3}$.

Koncepcja podmiotu Ricoeura - co stwierdza również autorka - jest próbą obrony kategorii podmiotowości w czasach, kiedy mówi się o śmierci podmiotu i kresie człowieka. Celem tej obrony nie jest powrót do Kartezjańskiego cogito. Jak pisze Adriana Warmbier:

Obrona idei podmiotowości jest opowiedzeniem się za takim rozumieniem podmiotu, którego konstytutywną własnością jest świadome odnoszenie się do siebie jako wolnej, autonomicznej i rozumnej istoty, której rozumność realizuje się w obecności licznych uwarunkowań i ograniczeń. Podmiotowość postkrytyczna to podmiotowość, która nie rozwija się w izolacji, wszakże dopiero brak izolacji stanowi jej warunek. W tym znaczeniu jest to podmiotowość heteronomiczna, relacyjna lub podmiotowość otwartej dialektyki ${ }^{4}$.

Z książki wyłania się obraz filozofii człowieka Ricoeura jako pewnej „drogi środka”, kompromisu między twardym ujęciem podmiotowości a jej brakiem. Autorka podkreśla, że w swojej książce chce bronić oryginalności myśli francuskiego

${ }^{2}$ Pisała zresztą o niej w przywołanym już artykule Podwójna struktura podmiotowości...

${ }^{3}$ Ibidem, ss. 332-333.

4 A. Warmbier, Tożsamość, narracja i hermeneutyka siebie. Paula Ricoeura filozofia człowieka, Kraków 2018, s. 22. 
filozofa, która polega na przedstawianiu alternatywnego podejścia, konsekwentnym i przemyślanym poszukiwaniu drogi pośredniej w dyskusjach dotyczących problematycznych zagadnień ${ }^{5}$. Warmbier trafnie zwraca uwagę, że dialektyka, którą opisuje Ricoeur, nie jest równoznaczna ze stworzeniem całościowej ontologii podmiotu otwartej dialektyki, czyli tego-który-jest-sobą-samym-jak-innym. Francuskiemu myślicielowi zależy raczej na wskazywaniu przyszłych możliwości ujęcia podmio$t^{6}$. Przechodząc do analizy koncepcji podmiotu dialektycznego, zwraca uwagę na zmiany pojęciowe, których dokonuje francuski filozof. Ricoeur próbuje na poziomie języka przekroczyć opozycyjność pojawiających się w Platońskim Parmenidesie pojęć „Ten Sam” oraz „Inny”. Zamiast pojęcia „Ten Sam” autor O sobie samym jako innym proponuje dialektykę znaczeń tożsamości idem (odnosi się do trwałej „struktury” tożsamości) oraz ipse (dopuszcza zmienność i nieciągłość).

Jednym z kluczowych elementów koncepcji podmiotu Ricoeura, o których pisze Adriana Warmbier, a być może nawet najważniejszym z nich, jest relacyjność. Wraz z narracyjnym charakterem tożsamości stanowi tak naprawdę istotę koncepcji Ricoeura, o której pisze autorka. W książce, co warto podkreślić, konstrukcja i rozwój podmiotu dokonuje się w relacji, w odniesieniu do inności, ale nie jest to coś danego raz na zawsze. Proces formowania własnej tożsamości oparty jest na czasowej, dynamicznej strukturze, zatem samookreślenie ani nie jest czymś danym, ani nie nabiera nigdy ostatecznego charakteru - jest to wyzwanie, zadanie do wykonania, które stoi przed podmiotem natrafiającym w trakcie jego realizacji na trudności i ograniczenia, które uniemożliwiają mu zdobycie pełnej wiedzy o sobie ${ }^{7}$.

Adriana Warmbier podkreśla w swojej książce potrzebę istnienia Innego, niezbędną przy konstruowaniu tożsamości. Pisze nawet o człowieku jako fenomenie określonym przez czas, w którym dokonuje się mediatyzacja „Tego Samego” i „Innego”. Myślenie o podmiocie w kontekście relacji, innych ludzi czy też wspólnoty jest zaznaczone także poprzez obecne w książce odniesienie do znanych komunitarystów, m.in. Charlesa Taylora i Alasdaira MacIntyre’a. Dla Ricoeura doświadczenie siebie jest zawsze efektem współobecności i współzależności sensów obu składowych bycia sobą i innego9 ${ }^{9}$.

Autorka wyraźnie akcentuje jeszcze jedną formę konstruowania się podmiotu. Relacyjna koncepcja podmiotowości odnosi się do Innego oraz do wspólnoty. U Ricoeura widać to nie tylko na poziomie deklaracji, ale także zabiegów na poziomie języka, kiedy dla podmiotu dialektycznego tworzy on de facto nową terminologię. Ważne jest jednak - i ten element zwrócił moją uwagę - że Ricoeur kładzie również nacisk na konstruowanie się podmiotu w odniesieniu do kultury,

\footnotetext{
${ }^{5}$ Ibidem, s. 58.

${ }^{6}$ Ibidem, s. 341.

7 Ibidem, s. 81.

${ }^{8}$ Ibidem, s. 38.

${ }^{9}$ Ibidem, s. 46.
} 
a mówiąc konkretniej, do znaków, symboli i mitów ${ }^{10}$. W tym kontekście Warmbier przywołuje słowa francuskiego myśliciela:

Cóż wiedzielibyśmy o miłości i nienawiści, o uczuciach etycznych i generalnie, o tym wszystkim co nazywamy sobq, gdyby nie zostało to napisane w języku i wyartykułowane przez literaturęę.

W tym kontekście rozumienie siebie zapośredniczone w języku symbolicznym wciela do refleksji historię kultury. W ten sposób refleksja staje się drogą do samopoznania wiodącą przez, wymienione już, symbole i mity.

Ricoeur w wielu swoich pracach pisze o tym, że „symbol daje do myślenia”. W kontekście symbolu religijnego daje on sens, którego jest źródłem. Natomiast dając „do myślenia”, pokazuje, że to, czego poszukuje człowiek, zostało powiedziane przez symbole, a zadaniem ludzi jest zawsze odtwarzać i przetwarzać to w wymiarze myślenia. Wychodząc od interpretacji symbolu, człowiek może dojść do refleksji na temat własnej egzystencji. Jest to trzeci - po fenomenologicznym i hermeneutycznym - poziom rozumienia symbolu religijnego według Paula Ricoeura. Ten przykład - zawężenia rozumienia symbolu do przestrzeni wyłącznie religijnej - wskazuje na to, że również w niej koncepcja podmiotu dialektycznego znajduje swoje zastosowanie. Autorka w odniesieniu do relacji między pragnieniem bycia a znakami przywołuje interesujący cytat z O pewnej filozoficznej interpretacji Freuda, w którym francuski filozof stwierdza, że podobnie jak Jean Nabert twierdzi, iż „symboliczne uniwersum jest środowiskiem samowyjaśnienia".

Ta deklaracja prowadzi Ricoeura do dwojakich wniosków. Po pierwsze, wynika z tego, że jeżeli znaki nie są środkiem i środowiskiem, dzięki któremu człowiek próbuje zrozumieć samego siebie, to zagadnienie sensu przestaje istnieć. Po wtóre jednak, Ricoeur zauważa, że zamiast przyswajania sobie własnego pragnienia istnienia na krótkiej drodze świadomości, pojawia się długa droga interpretacji znaków ${ }^{12}$. Wówczas zagadnienie sensu nie tyle przestaje istnieć, ile staje się trudniej dostępne, co w zasadzie jest bardziej odpowiednie dla koncepcji podmiotu dialektycznego opracowanego przez Francuza.

Tożsamość narracyjna stanowi istotny element koncepcji podmiotu dialektycznego. Widać to również w książce Warmbier, gdzie narracyjności w kontekście podmiotowości poświęcone jest sporo uwagi. Według Ricoeura ten rodzaj tożsamości stanowi rodzaj wyjścia poza alternatywę pojęcia tożsamości rozumianej jako coś niezmiennego (tożsamość idem - tego samego) bądź jako coś zbędnego. Tożsamość narracyjna jest swoistym pomostem prowadzącym do podmiotu otwartej dialektyki. Autorka pisze:

\footnotetext{
10 Ibidem, s. 32.

11 Ibidem, s. 38.

12 Ibidem, s. 220.
} 
Tożsamość narracyjna [...] oznacza zapośredniczoną długą drogę tego-który-jest-sobą do siebie samego poprzez urzeczywistnienie się w zdolności mówienia, działania, opowiadania o sobie i w doznawaniu oraz powracającego do siebie jako ten-który-jest-sobą-samym-jak-i-innym ${ }^{13}$.

Jest to myśl zaczerpnięta z Ricoeurowskiej Refleksji dokonanej. Powyższy cytat wskazuje na kwestie, które poruszane były wcześniej - konstruowanie tożsamości narracyjnej również ma relacyjny charakter.

W książce zaznaczony jest też aspekt refleksji w odniesieniu do podmiotowości. Ricoeur inspirując się Martinem Heideggerem i Hansem-Georgiem Gadamerem, zwraca uwagę na narracyjność samej refleksji ${ }^{14}$. Jak pisze Warmbier, narracyjność przy konstytuowaniu się podmiotu sposobem działania przypomina koło hermeneutyczne. Podmiot „dociera” do siebie poprzez krytyczne zapośredniczenie w tekstach, a konkretniej mówiąc, w wystawianym przez nie świecie. W ten sposób ten-który-jest-sobą staje się, jak powiada Ricoeur, dziełem czytania i interpretacji $^{15}$. Autorka trafnie zauważa, że koncepcja narracyjności francuskiego filozofa wpisuje się we współczesną refleksję humanistyczną. Narracyjność stanowi istotny element myśli m.in. wymienianych już Taylora i MacIntyre’a oraz Davida Carra i Roya Schafera. Według nich narracyjna koncepcja tożsamości ma swoje źródło w czasowości ludzkiej egzystencji. Ricoeur przyjmuje to myślenie i wskazuje na rolę kodów kultury w rozwijaniu samorozumienia. Według niego logika działania przyjmuje postać logiki narracji, jeśli zwraca się ku rozpoznanym kulturowym konfiguracjom, ku wzorcom przebiegu zdarzeń tworzonym przez rodzaje fabuły przekazane przez tradycję ${ }^{16}$.

Mówiąc o tradycji, nie można pominąć zagadnienia pamięci. Ten temat również został poruszony w książce Adriany Warmbier. Autorka wspomina zarówno o pamięci indywidualnej, jak i zbiorowej. Obie pełnią istotną rolę w kontekście narracyjności. Narracyjny charakter tożsamości wiąże się z tym, że podmiot - ten-który-jest-sobą - buduje swoją tożsamość, odnosząc się do tożsamości wspólnoty ukonstytuowanej w oparciu o pamięć zbiorową. W tym miejscu autorka trafnie stwierdza: „Odpowiedzieć na pytanie, kim jest ten-który-jest-sobą, znaczy opowiedzieć swoje życie”"17. Jak zauważa Ricoeur, nie jest to jednak bezpośrednia relacja, lecz życie poddane refleksji, oczyszczone i objaśnione przez opowieści czerpane z kultury.

Druga rola pamięci przy konstruowaniu tożsamości narracyjnej ma wymiar bardziej indywidualny. Pamięć, co może wydawać się oczywiste, wyznacza granice narracyjności. Krótko mówiąc, żeby tworzyć opowieść, należy pamiętać swoje przeżycia. To wiąże się oczywiście z zapominaniem i przypominaniem przez pod-

\footnotetext{
13 Ibidem, s. 41.

14 Ibidem, s. 82.

15 Ibidem, s. 83.

16 Ibidem, s. 227.

17 Ibidem, s. 266.
} 
miot wydarzeń z życia. Autorka zwraca uwagę także na aspekt pamięci wpisujący się w całość koncepcji Ricoeura - to, co zapamiętane, musi zostać opowiedziane, inaczej pozostaje martwe. Pamięć musi zostać zapośredniczona narracyjnie.

Udana analiza koncepcji podmiotu dialektycznego Ricoeura przez Adrianę Warmbier powoduje, że cel postawiony sobie przez autorkę książki zostaje osiągnięty. Myśl francuskiego filozofa wydaje się atrakcyjną „trzecią drogą” pomiędzy „twardym” podmiotem a jego brakiem. Autorka przedstawia Ricoeurowską myśl w sposób spójny i przekonujący. Wskazuje na jej genezę i inspirację oraz wpisuje w kontekst współczesnej myśli humanistycznej. Tożsamość narracyjna znajduje swoje miejsce wśród koncepcji narracyjności obecnych w humanistyce szczególnie w drugiej połowie XX wieku. O narracyjności piszą bowiem nie tylko Ricoeur, Taylor czy MacIntyre, ale również antropolodzy, np. Clifford Geertz. W koncepcji Ricoeura oraz w sposobie przedstawienia jej przez Adrianę Warmbier należy docenić wyraźny wymiar relacyjności. Podmiot staje się tym-który-jest-sobą dzięki Innemu i w relacji z nim. Wspólnota jest jedną z cech, które go konstytuują. Autorka, aby zilustrować znaczenie społeczności w tym kontekście, podaje przykład obietnicy. O jej roli w kulturze pisał nie tylko Ricoeur, ale także Hannah Arendt. Obietnica wymaga intersubiektywności - jest zawsze składana jakiemuś „Ty”, który oczekuje od tego-który-jest-sobą jej wypełnienia. To tylko jeden z przykładów ukazania znaczenia relacyjności przy konstruowaniu się podmiotu dialektycznego, o których pisze autorka.

Filozofia człowieka Ricoeura to rzeczywiście temat na książkę i omówienie jej poszczególnych elementów wymaga sporo czasu i uwagi. Jeżeli więc ktoś postanawia przygotować recenzję książki dotyczącej Ricoerowskiej filozofii człowieka, to nie chcąc napisać kolejnej książki, może jedynie wybrać pewne elementy z całości, które zwróciły jego uwagę. Wiele z fragmentów książki może stanowić punkt wyjścia do tworzenia kolejnych prac. Chociażby zagadnienie „podmiot a symbol”, nawet ograniczając się do samego Ricoeura, jest tematem bardzo rozległym i bogatym w konteksty.

W swojej recenzji chciałem uwypuklić rzeczy dla mnie najważniejsze w koncepcji Ricoeura - te, które, moim zdaniem, najwyraźniej były akcentowane przez autorkę. Podsumowując, książka Adriany Warmbier stanowi rzetelną analizę i zachętę do bliższego przyjrzenia się filozofii człowieka Paula Ricoeura. Autorce udało się wyraźnie zaznaczyć to, na czym chyba zależałoby samemu francuskiemu filozofowi, czyli fakt, że jego koncepcja jest czymś wykraczającym poza prostą alternatywę „twardy” podmiot - brak podmiotu, ale też nie jest pomysłem zamkniętym, lecz nadal otwartym na rozwój i reinterpretowanie. 